\title{
The periplasmic flagella of Serpulina (Treponema) hyodysenteriae are composed of two sheath proteins and three core proteins.
}

\author{
Marcel B. H. Koopman, ${ }^{1}$ Ellen BaAts, ${ }^{1}$ Camillo J. A. H. V. van Vorstenbosch, ${ }^{2}$ \\ Bernard A. M. VAN DER ZeIJST ${ }^{1}$ and Johannes G. Kusters ${ }^{1 *}$ \\ Department of Bacteriology ${ }^{1}$, Institute of Infectious Diseases and Immunology, and Department of Functional \\ Morphology 2, School of Veterinary Medicine, University of Utrecht, PO Box 80.165, 3508 TD Utrecht, The Netherlands.
}

(Received 30 March 1992; revised 1 June 1992; accepted 23 June 1992)

\begin{abstract}
The major components of the periplasmic flagella of the spirochaete Serpulina (Treponema) hyodysenteriae strain C5 were purified and characterized. We demonstrate that the periplasmic flagella are composed of five major proteins (molecular masses 44, 37, 35, 34 and $32 \mathrm{kDa}$ ) and present their location, $\mathrm{N}$-terminal amino acid sequence and immunological relationship. The $44 \mathrm{kDa}$ and the $35 \mathrm{kDa}$ protein are on the sheath of the periplasmic flagellum, whereas the 37,34 and $32 \mathrm{kDa}$ protein reside in the periplasmic flagellar core. The two sheath flagellar proteins are immunologically related but have different $\mathrm{N}$-terminal amino acid sequences. The $\mathrm{N}$-terminus of the $44 \mathrm{kDa}$ protein shows homology with the sheath flagellins of other spirochaetes, but the $35 \mathrm{kDa}$ protein does not. The three core proteins are immunologically cross-reactive and their $\mathrm{N}$-terminal amino acid sequences are almost, but not completely, identical, indicating that the core proteins are encoded by three distinct genes. The core proteins show extensive $\mathbf{N}$-terminal sequence similarities and an immunological relationship with periplasmic flagellar core proteins of other spirochaetes.
\end{abstract}

\section{Introduction}

The spirochaete Serpulina (Treponema) hyodysenteriae is the aetiological agent of swine dysentery (Harris et al., 1972; Taylor \& Alexander, 1971; Stanton, 1992), a severe mucohaemorrhagic diarrhoeal disease which primarily affects young pigs. The bacterium is highly motile by means of two bundles of seven to nine periplasmic flagella that are wound around the protoplasmic cylinder and are completely contained within the cell envelope in the periplasmic space. These periplasmic flagella are inserted subterminally at each pole and their ends overlap in the central portion of the bacterium (CanaleParola, 1978; Holt, 1978).

In a number of pathogenic bacteria, flagella appear to be an important viru'ence factor (Attridge \& Rowley, 1983; Drake \& Montie, 1987; Guentzel \& Berry, 1975; Holder et al., 1982; Morooka et al., 1985; Ochi et al., 1991 ; Pavlovskis et al., 1991; Richardson, 1991; Sadžiene et al., 1991; Wassenaar et al., 1991). Flagella may

* Author for correspondence. Tel. 3130 534987; fax 3130540784 .

The amino acid sequence data reported in this paper have been submitted to EMBL and assigned the accession numbers P80157 to P80161 (for the 44, 37, 35, 34 and $32 \mathrm{kDa}$ flagellins, respectively). also be an important virulence determinant of $S$. hyodysenteriae since they are involved in the typical corkscrew-like movement that facilitates the traverse by this bacterium of the viscous mucous lining the gut. They may therefore aid in the colonization of the gut and thus in causing disease. In addition, vaccination with a cloned periplasmic flagellar protein of $S$.hyodysenteriae was protective in a mouse model for swine dysentery (Boyden et al., 1989).

Most periplasmic flagella of spirochaetes contain multiple protein species, which form an inner core surrounded by a sheath or outer layer (Brahamsha \& Greenberg, 1988; Cockayne et al., 1987; Holt, 1978; Joseph \& Canale-Parola, 1972). However, the periplasmic flagella of Borrelia burgdorferi (Coleman \& Benach, 1989) and Treponema zuelzerae (Bharier \& Rittenberg, 1971) resemble other bacterial flagella: they do not have a sheath and consist of a single protein species. In spite of their role as a potential virulence factor and protective antigen little is known of the structure and composition of $S$. hyodysenteriae periplasmic flagella and conflicting data have been presented. Miller et al. (1988) reported the presence of six different proteins in periplasmic flagella of $S$.hyodysenteriae, ranging from 39 to $18.5 \mathrm{kDa}$. However, Kent et al. (1989) identified five 
major proteins, with molecular masses from 43.8 to $29.4 \mathrm{kDa}$. No further characterization of these proteins was presented. We therefore isolated periplasmic flagella of $S$. hyodysenteriae strain C5 in order to characterize their composition and structure in more detail. The major components of the periplasmic flagella were purified, their $\mathrm{N}$-terminal amino acid sequence was determined and their location on the flagella and immunological relationship were studied.

\section{Methods}

Bacterial strains and growth conditions. The origin and relevant characteristics of the $S$. hyodysenteriae strains used in this investigation are listed in Table 3 (see Results). Strongly haemolytic isolates were isolated from the gut of pigs severely affected by swine dysentery. Weakly haemolytic isolates originated from stools of pigs that suffered from diarrhoea but showed no other clinical signs of swine dysentery. $S$. hyodysenteriae was cultured at $40^{\circ} \mathrm{C}$ in an anaerobic hood, either in $250 \mathrm{ml}$ Trypticase Soy Broth supplemented with $10 \%$ foetal calf serum, $0.05 \%$ RNA core type II C from Torula yeast (Sigma) and $400 \mu \mathrm{g}$ spectinomycin $\mathrm{ml}^{-1}$, or on Trypticase Soy Agar (Becton Dickinson) plates supplemented with $10 \%(\mathrm{v} / \mathrm{v})$ sheep blood, $400 \mu \mathrm{g}$ spectinomycin $\mathrm{ml}^{-1}$ and $0.06 \%$ yeast extract (Oxoid).

Isolation and purification of the periplasmic flagella. A modification of the method described by Kent et al. (1989) was used. Bacterial cultures ( $250 \mathrm{ml}$ ) containing $10^{9}$ bacteria $\mathrm{ml}^{-1}$, were harvested by centrifugation at $15000 \mathrm{~g}$ for $30 \mathrm{~min}$ at $4{ }^{\circ} \mathrm{C}$ and washed once with phosphatebuffered saline (PBS; $0.14 \mathrm{M}-\mathrm{NaCl}, 2.7 \mathrm{mM}-\mathrm{KCl}, 0.01 \mathrm{M}-\mathrm{Na}_{2} \mathrm{HPO}_{4}$, $1.76 \mathrm{~mm}-\mathrm{KH}_{2} \mathrm{PO}_{4}, \mathrm{pH} 7 \cdot 3$ ). Pellets were suspended in $20 \mathrm{ml}$ of PBS and outer envelopes were removed by addition of $10 \%(w / v)$ SDS to a final concentration of $0.1 \%$ and incubating the suspension for $30 \mathrm{~min}$ at room temperature with gentle shaking. The organisms were collected by centrifugation at $25000 \mathrm{~g}$ for $30 \mathrm{~min}$ at $4{ }^{\circ} \mathrm{C}$ and resuspended in PBS. Periplasmic flagella were removed from the cells by shearing in a blender for a total of $10 \mathrm{~min}$. Pauses were included in which the suspension was cooled on ice to prevent overheating of the samples. Periplasmic flagella were separated from the bacterial bodies by collective pelleting of the latter at $30000 \mathrm{~g}$ for $30 \mathrm{~min}$ at $4{ }^{\circ} \mathrm{C}$. Sodium lauroylsarcosinate (Sarkosyl) was added $(0 \cdot 2 \%)$ to the supernatant and flagella were sedimented by centrifugation at $94000 \mathrm{~g}$ for $60 \mathrm{~min}$ at $4{ }^{\circ} \mathrm{C}$, resuspended in water and stored at $-20^{\circ} \mathrm{C}$.

Electrophoresis and Western blotting. Proteins were separated by SDS-PAGE $(12.5 \%, w / v$, acrylamide), essentially as described by Laemmli (1970). Proteins were visualized by staining with Coomassie Brilliant Blue R 250 and molecular masses were estimated by comparison with low molecular mass markers (Pharmacia). Proteins were transferred to nitrocellulose sheets (Schleicher and Schuell) according to the method of Towbin et al. (1979) using a Bio-Rad Transblot cell. After transfer, the nitrocellulose was blocked with $0.5 \%$

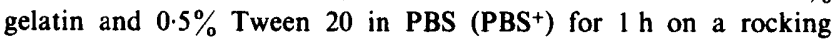
platform. The nitrocellulose was then incubated with an appropriate dilution of antiserum in $\mathrm{PBS}^{+}$for $1 \mathrm{~h}$. The filter was washed three times for $5 \mathrm{~min}$ with $\mathrm{PBS}^{+}$and further incubated for $1 \mathrm{~h}$ with a $1: 3000$ dilution of an alkaline phosphatase conjugate of either goat anti-rabbit immunoglobulin G (Sigma) or a 1:2000 dilution of goat anti-mouse immunoglobulin G (Promega) in PBS $^{+}$. After three washings with $\mathrm{PBS}^{+}$, bound antibodies were visualized by development in nitro blue tetrazolium $(0.37 \mathrm{mM})$ and 5-bromo-4-chloro-3-indolyl phosphate $(0.34 \mathrm{~mm})$ solubilized in $100 \mathrm{~mm}-\mathrm{Tris} / \mathrm{HCl}, 100 \mathrm{~mm}-\mathrm{NaCl}, 5 \mathrm{~mm}-$ $\mathrm{MgCl}_{2}, \mathrm{pH} 9 \cdot 5$. Incubations and washings were performed at room temperature on a rocking platform.
Electron microscopy. S. hyodysenteriae cells were grown for $3 \mathrm{~d}$ on Trypticase Soy Agar plates and collected in $2 \mathrm{ml} 0.03 \%$ sucrose, $0.01 \mathrm{M}$ $\mathrm{MgCl}_{2}, 0.01 \mathrm{M}-\mathrm{CaCl}_{2}$. Samples were applied to Pioloform-coated copper grids (200 mesh, Bio-Rad) for $10 \mathrm{~min}$, then washed briefly three times on drops of water and negatively stained with phosphotungstic acid (PTA). For immunogold labelling, bacteria were adsorbed onto grids and rinsed briefly three times with water. Subsequently, they were incubated for $30 \mathrm{~min}$ on drops of $1: 1000$-diluted antiserum in PBT (PBS containing $1 \%$ BSA, $0.05 \%$ Tween 20 and $0.1 \%$ gelatin). After three rinses with PBT, grids were further incubated for $30 \mathrm{~min}$ with protein A conjugated with $10 \mathrm{~nm}$ gold particles (Janssen Life Sciences). After rinsing the grids twice with water, the samples were negatively stained with PTA. All samples were examined with a Philips 201 electron microscope operating at $60 \mathrm{kV}$ and an objective aperture of $30 \mu \mathrm{m}$.

Antisera. Rabbit antisera to the individual components of purified periplasmic flagella of $S$. hyodysenteriae $\mathrm{C} 5$ were obtained as follows. Approximately $600 \mu \mathrm{g}$ of flagellar proteins was separated by SDSPAGE, blotted onto nitrocellulose filters and visualized by staining with $0.6 \%$ Ponceau Red in 3\% trichloroacetic acid. The areas of the filters containing the desired proteins were cut-out, shock-frozen in liquid nitrogen and homogenized with a Braun Mikro-dismembrator. The homogenized material was suspended in $3 \mathrm{ml}$ of water and stored at $-20^{\circ} \mathrm{C}$. For immunization, $1.5 \mathrm{ml}$ of this material was mixed with an equal volume of Freund's complete adjuvant and inoculated intramuscularly into a New Zealand White rabbit on day 0 . The rabbit was boosted with $1.5 \mathrm{ml}$ of homogenized antigen/nitrocellulose in an equal volume of Freund's incomplete adjuvant on day 28 . Sera were collected at days $-1,20,34,41$ and 48 .

Rabbit antiserum to Treponema phagedenis biotype Reiter periplasmic flagella was a gift from G. Noordhoek, RIVM Bilthoven, The Netherlands. Mouse monoclonals .1H11G7 and .2A6B4 and rabbit serum against Spirochaeta aurantia periplasmic flagella were obtained from E. P. Greenberg, University of Iowa, USA (Brahamsha \& Greenberg, 1988). Mouse monoclonal mCC9 to the $37 \mathrm{kDa}$ Treponema pallidum periplasmic flagellar protein was from $\mathrm{C}$. W. Penn, University of Birmingham, UK (Bailey et al., 1987).

$N$-Terminal sequence analysis. Periplasmic flagellar proteins were separated by SDS-PAGE and electroblotted on polyvinylidene difluoride membranes (Immobilon transfer membranes; Millipore) in $10 \mathrm{~mm}$-3-cyclohexylamino-1,1-propanesulphonic acid, $\mathrm{pH} 11.0$ and $10 \%$ methanol. The blotted proteins were stained with Coomassie Brilliant Blue R250 and bands containing the proteins of interest were cut-out. The amino acid sequence of the blotted proteins was determined with an Applied Biosystems model 470A protein sequencer, on-line equipped with a model 120A PTH Analyzer.

\section{Results}

\section{Purification and SDS-PAGE analysis of periplasmic flagellar proteins}

To identify the proteins that constitute the periplasmic flagella of $S$. hyodysenteriae, the periplasmic flagellar proteins of $S$. hyodysenteriae strain $C 5$ were separated by SDS-PAGE. Five major proteins with apparent molecular masses of 44, 37, 35, 34 and $32 \mathrm{kDa}$ were observed (Fig. 1, lane B). Bands of 44 and $37 \mathrm{kDa}$ could be discerned clearly in a whole cell lysate of $S$. hyodysenteriae C5 (Fig. 1, lane A) suggesting that they are abundant proteins in the bacterium. In some periplasmic flagellar 
A

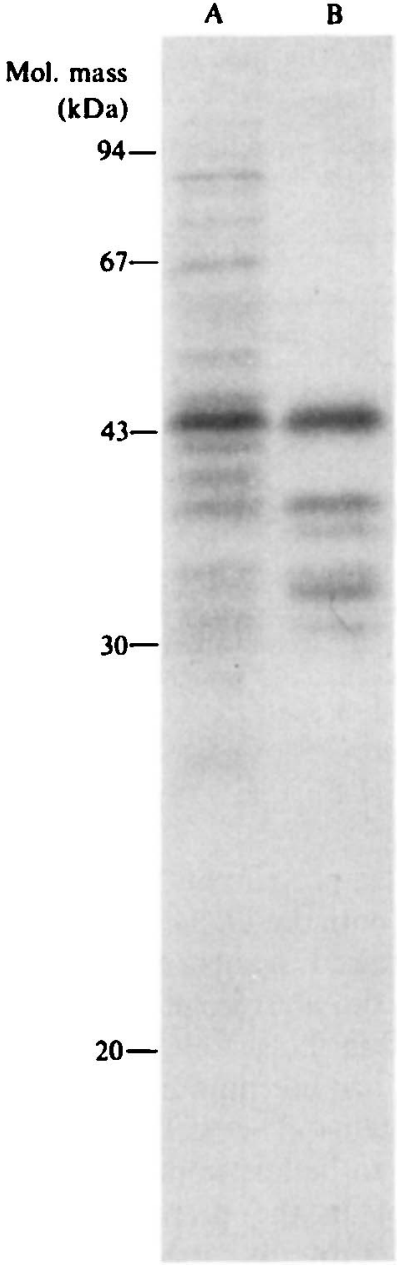

Fig. 1. SDS-PAGE analysis of whole cell lysate (lane A) and isolated flagella (lane B) of $S$.hyodysenteriae $\mathrm{C} 5$ stained with Coomassie Brilliant Blue R250. preparations the $34 \mathrm{kDa}$ band appeared as a doublet (as in Fig. 1, lane B) or two additional bands of 30 and $28 \mathrm{kDa}$ were visible. Since these bands were not always present and were of low intensity they may be minor periplasmic flagellar proteins, breakdown products or contaminants.

\section{Immunoblot analysis of periplasmic flagellar protein}

Further evidence for the flagellar nature of the five major proteins present in the periplasmic flagellar preparations was obtained by their reactivity on immunoblots with sera and monoclonal antibodies that had been raised against periplasmic flagellar proteins of other spirochaetes. With the exception of the 30 and $28 \mathrm{kDa}$ proteins, all proteins present in the periplasmic flagellar preparation reacted with one or more of these sera (Table 1). The data obtained also show that the 37,34 and $32 \mathrm{kDa}$ proteins are immunologically related.

Rabbit antisera raised to the individual periplasmic flagellar proteins of $S$. hyodysenteriae strain C5 were tested in immunoblots for reactivity with $S$. hyodysenteriae C5 lysate and purified periplasmic flagella. An example of these immunoblots is shown in Fig. 2. Table 2 summarizes the results of the experiments. When Western blots with purified flagella were immunostained with serum raised against the $44 \mathrm{kDa}$ flagellar protein, a strong $44 \mathrm{kDa}$ band and a weak $35 \mathrm{kDa}$ band appeared (Fig. 2, lane 1B). Other bands did not stain, even after prolonged development of the immunoblots. This confirms that the 44 and $35 \mathrm{kDa}$ proteins are immunologically related. When Western blots with $S$. hyodysenteriae C5 lysate were incubated with anti$44 \mathrm{kDa}$ serum, a $44 \mathrm{kDa}$ band readily appeared, but a

Table 1. Western blot reactions of $S$. hyodysenteriae C5 periplasmic flagella-associated proteins and cell lysates probed with antisera against flagella of other spirochaetes

Reactivity is scored as - (no signal above background), + (weak reactivity) or +++ (strong reactivity)

\begin{tabular}{|c|c|c|c|c|c|}
\hline \multirow[b]{2}{*}{ Protein* } & \multicolumn{5}{|c|}{ Reactivity with: $†$} \\
\hline & $\mathrm{R} \alpha \mathrm{TPRPF}$ & $\mathrm{R} \alpha \mathrm{SAPF}$ & $.2 \mathrm{~A} 6 \mathrm{~B} 4$ & $.1 \mathrm{H} 11 \mathrm{G} 7$ & $\mathrm{mCC} 9$ \\
\hline 44 & + & + & - & - & - \\
\hline 37 & +++ & +++ & +++ & - & - \\
\hline 35 & - & - & - & - & + \\
\hline 34 & +++ & $++t$ & +++ & + & - \\
\hline 32 & +++ & +++ & - & + & - \\
\hline 30 & - & - & - & - & - \\
\hline 28 & - & - & - & - & - \\
\hline
\end{tabular}

* Molecular mass of flagella-associated proteins in $\mathrm{kDa}$.

$+\mathrm{R} \alpha \mathrm{TPR} P \mathrm{~F}$, rabbit serum against periplasmic flagella of $T$. phagedenis biotype Reiter 1; R $\alpha \mathrm{SAPF}$, rabbit serum against periplasmic flagella of $S$. aurantia; mCC9, monoclonal antibody against the $37 \mathrm{kDa}$ periplasmic flagellar sheath protein of $T$. pallidum (Bailey et al., 1987); .2A6B4, monoclonal antibody primarily against the $31.5 \mathrm{kDa}$ periplasmic flagellar protein of $S$. aurantia (Brahamsha \& Greenberg, 1988); .1H11G7, monoclonal antibody against the 31.5 and $34 \mathrm{kDa}$ periplasmic flagellar proteins of $S$. aurantia (Brahamsha \& Greenberg, 1988). 


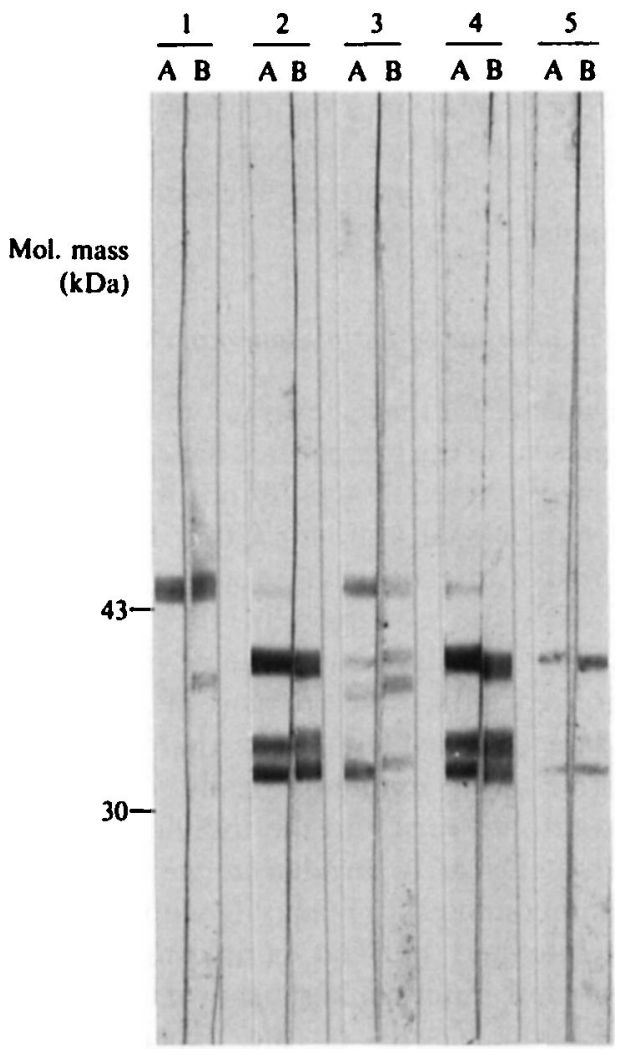

Fig. 2. Immunoblot analysis of $S$. hyodysenteriae $\mathrm{C} 5$ flagellar proteins. Rabbit antisera against the individual flagellar proteins were reacted with cell lysate of $S$. hyodysenteriae C5 (lanes A) and purified flagella (lanes B). Blots were incubated with sera to the 44 (lanes 1), 37 (lanes 2), 35 (lanes 3), 34 (lanes 4) and 32 (lanes 5) kDa flagellar proteins.

$35 \mathrm{kDa}$ band did not become visible (Fig. 1, lane A). This is probably because preparations of whole bacteria contain relatively low amounts of the $35 \mathrm{kDa}$ protein as compared to preparations of purified flagella. Sera raised against the 37 or $34 \mathrm{kDa}$ proteins reacted with the 37,34 and $32 \mathrm{kDa}$ proteins (Fig. 2, lanes 2 and 4). Sera raised against the $32 \mathrm{kDa}$ protein reacted not only with the $32 \mathrm{kDa}$ protein, but recognized the $37 \mathrm{kDa}$ protein as well, although weakly (Fig. 2, lane 5). These findings show that the 37,34 and $32 \mathrm{kDa}$ proteins share epitopes. The anti-35 kDa serum reacted weakly with both the $35 \mathrm{kDa}$ protein and the $44 \mathrm{kDa}$ protein (Fig. 2, lane 3), confirming the immunological relationship observed between these two proteins in lane $1 \mathrm{~B}$. The serum also reacted weakly with the other proteins present in the preparation. However, this cross-reaction is probably due to the way in which the $35 \mathrm{kDa}$ protein was isolated: it is plausible that the $37 \mathrm{kDa}$ protein contaminated the preparation when cut-out from Western blots. Thus, immunization of rabbits with this preparation not only resulted in the production of antibodies that recognized
Table 2. Western blot reactions of $S$. hyodysenteriae $C 5$ periplasmic flagella-associated proteins and cell lysates probed with antisera against individual flagellar components

Reactivity is scored as - (no signal above background), + (weak reactivity), ++ (moderate reactivity) or +++ (strong reactivity).

\begin{tabular}{cccccc}
\hline & \multicolumn{5}{c}{ Reactivity with: } \\
\cline { 2 - 6 } Protein* & $\alpha 44$ & $\alpha 37$ & $\alpha 35$ & $\alpha 34$ & $\alpha 32$ \\
\hline 44 & +++ & - & + & - & - \\
37 & - & +++ & + & +++ & ++ \\
35 & + & - & + & - & - \\
34 & - & +++ & + & +++ & - \\
32 & - & +++ & + & +++ & + \\
30 & - & - & - & - & - \\
28 & - & - & - & - & - \\
\hline \hline
\end{tabular}

* Molecular mass of flagella-associated proteins in $\mathrm{kDa}$

$\dagger \alpha 44, \alpha 37, \alpha 35, \alpha 34$ and $\alpha 32$ are rabbit immune sera raised against purified $44,37,35,34$ and $32 \mathrm{kDa}$ periplasmic flagellar proteins, respectively, of $S$. hyodysenteriae $\mathrm{C} 5$.

the 44 and $35 \mathrm{kDa}$ protein, but also produced antibodies that recognized both the 37,34 and $32 \mathrm{kDa}$ proteins. The fact that sera raised against either one of these three related proteins did not recognize the $35 \mathrm{kDa}$ protein or the $44 \mathrm{kDa}$ protein showed already that the $44 \mathrm{kDa}$ and $35 \mathrm{kDa}$ protein are not immunologically related to the other three proteins. The $35 \mathrm{kDa}$ protein and $32 \mathrm{kDa}$ protein seemed to be less immunogenic than the other proteins present in the preparation: antisera raised against these proteins reacted only weakly on immunoblots.

\section{Immunogold labelling of S. hyodysenteriae periplasmic flagella}

To investigate whether the proteins present in periplasmic flagellar preparations of $S$. hyodysenteriae C5 are exclusively localized in the periplasmic flagella we used the rabbit antisera raised against the individual components of the periplasmic flagella in immunogold electron microscopy experiments. In each of the 20 samples (prepared in four separate experiments) antibodies that react with the $44 \mathrm{kDa}$ and the $35 \mathrm{kDa}$ protein specifically decorated the periplasmic flagella along their entire length (Fig. $3 a$ ). Occasionally, periplasmic flagella were observed that were labelled except for their distal parts. When antibodies that recognize the 37,34 and $32 \mathrm{kDa}$ protein were used for immunogold labelling, reactivity with the ends of periplasmic flagella only was observed. Occasionally, the antisera labelled the flagella in scattered areas (Fig. $3 b$ ). The majority of the periplasmic flagella that were observed on the 20 grids examined (prepared in four independent experiments) were 

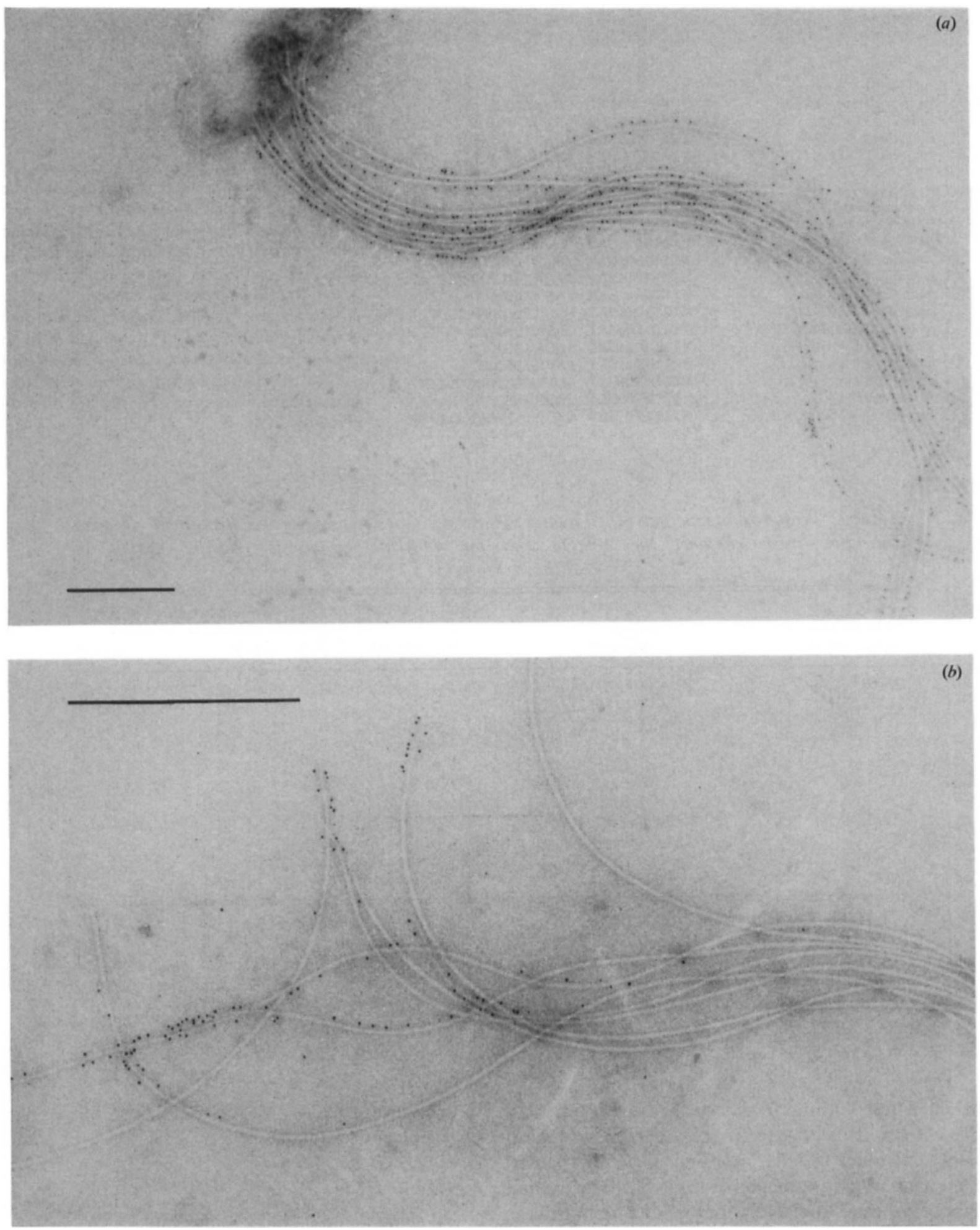

Fig. 3. Immunogold electron-microscopy after incubation of $S$. hyodysenteriae $\mathrm{C} 5$ with antiserum to the $44 \mathrm{kDa}(a)$ and $37 \mathrm{kDa}(b)$ flagellar protein. Bars, $400 \mathrm{~nm}$. 
(a) S. hyodysenteriae $44 \mathrm{kDa}$ S. hyodysenteriae $37 \mathrm{kDa}$ $S$. hyodysenteriae $35 \mathrm{kDa}$

$S$. hyodysenteriae $34 \mathrm{kDa}$

$S$. hyodysenteriae $32 \mathrm{kDa}$

(b) S. hyodysenteriae $44 \mathrm{kDa}$ T. pallidum $37 \mathrm{kDa}$

T. phagedenis $39 \mathrm{kDa}$

S. aurantia $37 \mathrm{kDa}$

(c) S. hyodysenteriae $37 \mathrm{kDa}$ $S$. hyodysenteriae $34 \mathrm{kDa}$ $S$. hyodysenteriae $32 \mathrm{kDa}$

T. pallidum fla B

T. pallidum fla B2

T. pallidum fla B3

$T$. phagedenis $34 \mathrm{kDa}$

$T$. phagedenis $33 \mathrm{kDa}$

$S$. aurantia major $34 \mathrm{kDa}$

$S$. aurantia minor $33 \mathrm{kDa}$

$S$. aurantia minor $32 \mathrm{kDa}$

$S$. aurantia major $31.5 \mathrm{kDa}$

B. burgdorferi $41 \mathrm{kDa}$

L. borgpetersenii $32 \mathrm{kDa}$
LSNSTLIDFA LTGNADNLQ

MVINNNISAI NAQRTLKFRQ VDLKK -ETVPYMFEN

MIINNNISAI NAORTLKFRN VDL-R MIINNNISAL NANRQLNLTG NSMTK

I SNSTLIDFAL TGNADNLQ DESVLIDFAK LNADIMADKS GGMTH EQATLIDFGK LNADIVDDKN GGMTQ EQATLIDFSK LVGEGNTGLH APTTI

MVINNNISAI NAQRTLKFRQ VDLKK MIINNNISAI NAORTLKFRN VDL-R MIINNNISAL NANRQLNLTG NSMTK MIINHNMSAM FAQRTLGHTN VOVGK MIINHNMSAM FSQRTLGHTN LSVQK MIINHNMSAM FAQRQGGING LAIAK MIINHNMSAM FAQRTIGVTN NAIGK MIINHNMSAM FAORTLGNTN LSVOK MIINHNMSAI NAQRVQGBVT GVTKN MIINHNMSAI NAQXVQGBVT MIINHNMSAI NANRVLGBT

MIINHNMSAI NANRVLGBTN ADITK MIINHNTSAI NASRNNGINA NLSKT MI INHNLSAV NSHRSLKFNE LAVDK
Fig. 4. N-terminal amino acid sequences of the $S$. hyodysenteriae C5 flagellar proteins (a) and comparison with flagellar sheath $(b)$ and core $(c)$ proteins of T. pallidum (Champion et al., 1990; Isaacs et al., 1989; Norris et al., 1988; Pallesen \& Hindersson, 1989), T. phagedenis (Norris et al., 1988) and S. aurantia (Brahamsha \& Greenberg, 1989; Parales \& Greenberg, 1991). The single flagellin of B. burgdorferi (Wallich et al., 1990) and a periplasmic flagellar protein of Leptospira borgpetersenii (Mitchison $e t$ al., 1991) are included in group (c). The identity of underlined residues could not be determined with certainty.

Table 3. Western blot reactions of cell lysates of several isolates and strains of S. hyodysenteriae with antiserum raised against the $37 \mathrm{kDa}$ and the $44 \mathrm{kDa}$ periplasmic flagellar protein of $S$. hyodysenteriae $C 5$

\begin{tabular}{|c|c|c|c|c|}
\hline \multirow{2}{*}{$\begin{array}{l}\text { S. hyodysenteriae } \\
\text { isolate/strain }\end{array}$} & \multirow[b]{2}{*}{ Source* } & \multirow[b]{2}{*}{ Haemolysis $\dagger$} & \multicolumn{2}{|c|}{ Proteins reactive with: $:$} \\
\hline & & & anti-37 & anti- $44 \S$ \\
\hline 27164 & ATCC 27164 & $+t+$ & $37,34,32$ & 44 \\
\hline 31212 & ATCC 31212 & +++ & $37,34,32$ & 44 \\
\hline 31287 & ATCC 31287 & +++ & $37,34,32$ & 44 \\
\hline B8 & FI & +++ & $37,34,32$ & 44 \\
\hline C5 & FI & $+t+$ & $37,34,32$ & 44 \\
\hline D2 & FI & $+1-$ & $37,34,32$ & 47 \\
\hline D7 & FI & $+1-$ & $37,34,32$ & 45 \\
\hline PWS/A & Hudson et al. (1976) & $+1-$ & $37,34,32$ & 44 \\
\hline $\mathrm{Z7}$ & FI & +++ & $37,34,32$ & 44 \\
\hline $\mathrm{Z} 10$ & FI & +++ & $37,34,32$ & 44 \\
\hline $\mathrm{Z} 12$ & FI & $+1-$ & $37,34,32$ & 46 \\
\hline
\end{tabular}

* FI, Dutch field isolate.

$\dagger+1-$, Weakly haemolytic; +++ , strongly haemolytic.

$\ddagger$ The molecular masses given are those of proteins reactive with rabbit serum to the $37 \mathrm{kDa}$ and $44 \mathrm{kDa}$ flagellar proteins of $S$. hyodysenteriae $\mathrm{C} 5$.

$\S$ Weak reactivity with a $35 \mathrm{kDa}$ protein was noted in each of the $S$. hyodysenteriae tested.

unlabelled. These findings indicate that epitopes that are reactive with the antisera used in this experiment are not accessible on intact flagella, and only become exposed when an outer layer is damaged or removed. The finding that labelling occurs mostly at the tips of the flagella is probably due to a high susceptibility of the ends of flagella to damage caused during preparation of the samples for electron microscopy. Gold particles were not observed to be attached to the outer envelope or other structures of the bacterium with any of the rabbit antisera raised against the individual components of the periplasmic flagella.

\section{$N$-Terminal amino acid sequencing}

All major proteins present in the periplasmic flagella preparation were further characterized by $\mathrm{N}$-terminal amino acid sequencing. The $\mathrm{N}$-terminal amino acid sequences obtained are listed in Fig. $4(a)$. The $\mathrm{N}$ - 
terminal amino acid sequences of the 37,34 and $32 \mathrm{kDa}$ proteins are highly similar. This supports the conclusion, based on antigenic relatedness, that the three polypeptides are similar. The $\mathrm{N}$-terminal sequences of the 44 and $35 \mathrm{kDa}$ protein are distinct from each other and from those of the other proteins in the periplasmic flagellar preparation.

\section{Similarities of the N-terminal sequences of}

$S$. hyodysenteriae flagellins to other flagellins

A comparison was made between the $\mathbf{N}$-terminal sequences of the $S$. hyodysenteriae periplasmic flagellar proteins and amino acid sequences present in the NBRF (release 28.0) and Swiss-prot (release 18.0) databases, the $\mathrm{N}$-terminal amino acid sequences of periplasmic flagellar proteins of S. aurantia (Parales \& Greenberg, 1991) and a Leptospira borgpetersenii periplasmic flagellar subunit protein (Mitchison et al., 1991). This search revealed no significant similarities to the $\mathrm{N}$-terminal sequence of the $35 \mathrm{kDa}$ protein. The $44 \mathrm{kDa}$ protein shared some $\mathrm{N}$-terminal amino acid residues with the periplasmic flagellar sheath proteins of $T$. pallidum, $T$. phagedenis and $S$. aurantia (Fig. $4 b$ ), whereas the $\mathrm{N}$ termini of the 37,34 and $32 \mathrm{kDa}$ proteins are very similar to those of the core proteins of other spirochaetes (Fig. $4 c)$.

\section{Antigenic conservation of periplasmic flagellar proteins within various isolates of $S$. hyodysenteriae}

We used our monospecific sera to the individual flagellins to examine the conservation of periplasmic flagellar antigens of $S$. hyodysenteriae. Cell lysates of three ATCC reference strains and seven Dutch field strains of $S$. hyodysenteriae, isolated from pigs severely affected by swine dysentery, were reacted in immunoblots with serum raised against the individual flagellins of $S$. hyodysenteriae $\mathrm{C} 5$. Only the results of immunoblotting experiments with the anti-37 kDa and the anti$44 \mathrm{kDa}$ sera are shown (Table 3), since corresponding results were obtained with the anti-37, $-34,-32$ and the anti- 44 and $-35 \mathrm{kDa}$ sera respectively.

All isolates tested possessed proteins of $37,35,34$ and $32 \mathrm{kDa}$, which reacted with serum raised against proteins of the same molecular mass in $S$. hyodysenteriae C5. In contrast, the molecular mass of the largest periplasmic flagellar protein varied between isolates: in strongly haemolytic isolates it was $44 \mathrm{kDa}$, whereas in weakly haemolytic isolates it varied between 44 and $47 \mathrm{kDa}$.

\section{Discussion}

The objective of the present study was to characterize the structure and composition of periplasmic flagella of $S$. hyodysenteriae strain C5. Periplasmic flagella of $S$. hyodysenteriae are the organelles of motility and serve as protective antigens (Boyden et al., 1989; Chatfield et al., 1988; Kent et al., 1989). It has been suggested that motility is the major mechanism by which $S$. hyodysenteriae colonizes the colonic mucosa of pigs (Kennedy et al., 1988) and thus it may augment virulence of the bacterium. Flagellar preparations of $S$. hyodysenteriae C5 contained five major proteins with molecular masses of 44, 37, 35, 34 and $32 \mathrm{kDa}$. Electron microscopy with immunogold labelling demonstrated that these proteins form a flagellar core surrounded by a sheath. Antisera that recognize both the 44 and $35 \mathrm{kDa}$ proteins decorated the periplasmic flagella along their entire length, indicating that at least one of these two proteins is located on the sheath. The 37,34 , and $32 \mathrm{kDa}$ proteins reside in the core, since specific antisera to these proteins labelled the periplasmic flagella only at the tips and occasionally in scattered areas, presumably where no sheath is present or where it has been damaged or removed due to breakage of the periplasmic flagella when preparing the samples for electron microscopy. Often flagella did not label with sera recognizing the 37 , 34 , and $32 \mathrm{kDa}$ proteins. This is in agreement with the proposal that in intact flagella these proteins are completely surrounded by an outer layer of sheath protein and thus not accessible to antibodies. With antisera recognizing both the $44 \mathrm{kDa}$ and $35 \mathrm{kDa}$ protein we occasionally observed flagella that were labelled entirely, except for the distal parts. This illustrates that this antiserum does not react with proteins that are exposed at the tips (i.e. those proteins which reside in the flagellar core), strongly suggesting that both the $44 \mathrm{kDa}$ protein and the $35 \mathrm{kDa}$ protein are located exclusively on the sheath.

In agreement with our results, Kent et al. (1989) identified five major proteins in periplasmic flagella of $S$. hyodysenteriae, with molecular masses of $43.8,38$, $34.8,32.8$ and $29.4 \mathrm{kDa}$. However, Miller et al. (1988) reported that $S$. hyodysenteriae periplasmic flagella consist of six proteins, with appproximate molecular masses of $39,29,27,22,21,18.5 \mathrm{kDa}$. The difference in number and molecular masses of periplasmic flagellar proteins, when compared to our results and to those of Kent $e t$ al. (1989), may be related to the different method used to isolate the periplasmic flagella and for subsequent electrophoretic analysis.

The $44 \mathrm{kDa}$ flagellar sheath protein shows $\mathrm{N}$-terminal amino acid similarity with the sheath flagellins of $T$. pallidum (Isaacs \& Radolf, 1990) and S.aurantia 
(Parales \& Greenberg, 1991). Its N-terminal amino acid sequence does not start with a methionine residue, indicating that the protein is post-translationally modified. Most likely, a signal sequence is cleaved-off before assembly onto flagella in the periplasmic space, as reported for the sheath flagellin of $T$. pallidum (Isaacs \& Radolf, 1990) and S. aurantia (Parales \& Greenberg, 1991). Post-translational modification or degradation of the $44 \mathrm{kDa}$ protein could yield the $35 \mathrm{kDa}$ sheath flagellar protein. The immunological cross-reactivity of the two proteins supports such a relationship. Alternatively, the $35 \mathrm{kDa}$ protein is the product of a separate gene. An indication for this is that monoclonal antibody mCC9, which specifically recognizes the sheath protein in $T$. pallidum (Bailey et al., 1987) reacts exclusively with the $35 \mathrm{kDa}$ protein on Western blots but not with the $44 \mathrm{kDa}$ protein.

The 37, 34 and $32 \mathrm{kDa}$ proteins show an extensive Nterminal sequence identity with each other and with other spirochaete periplasmic flagellar core proteins (Champion et al., 1990; Coleman \& Benach, 1989; Mitchison et al., 1991; Norris et al., 1988; Pallesen \& Hindersson, 1989; Parales \& Greenberg, 1991). The Nterminal region of the core proteins also shows some similarity to flagellar proteins of remotely related bacteria (DeLange et al., 1976; Kuwajima et al., 1986; Martin \& Savage, 1988; Wei \& Joys, 1985), indicating that these proteins have an important role, e.g. in the function or assembly of the flagellum. We assume that the three core flagellar proteins are encoded by different genes, since the $\mathrm{N}$-terminal amino acid sequences of these proteins are similar, but not identical. This would resemble the situation in $T$. pallidum where each of the three core proteins is the product of a distinct gene (Champion et al., 1990; Pallesen \& Hindersson, 1989).

SDS-PAGE profiles of flagellar preparations clearly show that the various flagellar proteins are present in different quantities. This phenomenon has been observed by Kent et al. (1989) and also by other workers studying different spirochaetes (Blanco et al., 1988; Brahamsha \& Greenberg, 1989; Limberger \& Charon, 1986). We cannot explain why these differences exist in $S$. hyodysenteriae. Although we cannot exclude the possibility that these differences are the result of our purification method, it may be that the flagellar proteins are present on the same periplasmic flagellum in different amounts. It is also possible that there exist different periplasmic flagella, each composed of a single type of core or sheath protein. The precise distribution of the flagellar proteins on the periplasmic flagella can be determined with antibodies that discriminate between the flagellins but at the moment these antibodies are not available. We attempted to localize the $35 \mathrm{kDa}$ protein on the periplasmic flagella using monoclonal antibody
mCC9. However, in these immunogold labelling experiments reactivity was never observed. Apparently, the epitope that is recognized by the monoclonal antibody on Western blots is not available for binding on nondenatured periplasmic flagella. Cockayne et al. (1987) reported that a proportion of the sheathed filaments of $T$. pallidum failed to react with monoclonal antibody mCC9, and suggested that antigenic heterogeneity was present within the population of sheathed filaments.

The $44 \mathrm{kDa}$ flagellin seems to be the periplasmic flagellar protein that is least constrained by functional demands. Thus, in spirochaetes isolated from swine, variation in the molecular mass of this protein was observed whereas the molecular masses of the other flagellins were conserved. It is noteworthy that variation in molecular mass was observed exclusively with weakly haemolytic isolates, originating from stools of pigs that suffered from diarrhoea but showed no other clinical signs of swine dysentery. All strongly haemolytic isolates, originating from the gut of pigs severely affected by swine dysentery, had a $44 \mathrm{kDa}$ sheath protein. This suggests the intriguing possibility that there is a relationship between virulence and the structure of the sheath of $T$. pallidum subspp. pallidum and pertenue pathogen-specific determinant is located on the flagellar sheath of $T$. pallidum subsp. $P$. pallidum and pertenue (Lukehart et al., 1985) and on invasive oral spirochaetes from dental plaque (Reviere et al., 1991), but there is no evidence that this pathogen-specific determinant is directly involved in virulence. Currently, the hypothesis that the structure of the flagellar sheath protein may influence virulence remains mere speculation. Our characterization of the periplasmic flagellar proteins of $S$. hyodysenteriae will enable the isolation of the flagellar genes and allow their potential function in virulence of $S$. hyodysenteriae to be addressed.

The work was supported by Solvay Duphar BV, Weesp, The Netherlands. We gratefully acknowledge the use of the services and facilities of the Dutch National NWO/SURF Expertise Centre CAOS/CAMM, under grant numbers SON 326-052 and STW NCH99.1751 and the Gas Phase Sequenator Facility (Department of Medical Biochemistry, State University of Leiden, The Netherlands), which is supported by the Netherlands Organization for Scientific Research (NWO) through the Netherlands Foundation for Chemical Research (SON). We thank A. A. H. M ter Huurne for helpful discussion and donating field isolates of $S$. hyodysenteriae.

\section{References}

AtTRIDGe, S. R. \& Rowley, D. (1983). The role of the flagellum in the adherence of Vibrio cholerae. Journal of Infectious Diseases 147, 864 872.

Bailey, M. J., Cockayne, A. \& Penn, C. W. (1987). Production of murine monoclonal antibodies to the major axial filament polypeptide of Treponema pallidum. Journal of General Microbiology 133, 1805-1813. 
Bharier, M. A. \& Rittenberg, S. C. (1971). Chemistry of axial filaments of Treponema zuelzerae. Journal of Bacteriology 105, 422429.

Blanco, D. R., Champion, C. I., Miller, J. N. \& Lovett, M. A. (1988). Antigenic and structural characterization of Treponema pallidum (Nichols strain) endoflagella. Infection and Immunity 56, $168-175$.

Boyden, D. A., Albert, F. G. \& Robinson, C. S. (1989). Cloning and characterization of Treponema hyodysenteriae antigens and protection in a CF-1 mouse model by immunization with a cloned endoflagellar antigen. Infection and Immunity 57, 3808-3815.

Brahamsha, B. \& Greenberg, E. P. (1988). A biochemical and cytological analysis of the complex periplasmic flagella from Spirochaeta aurantia. Journal of Bacteriology 170, 4023-4032.

Brahamsha, B. \& Greenberg, E. P. (1989). Cloning and sequence analysis of $f a A$, a gene encoding a Spirochaeta aurantia flagellar filament surface antigen. Journal of Bacteriology 171, 1692-1697.

Canale-Parola, E. (1978). Motility and chemotaxis of spirochetes. Annual Review of Microbiology 32, 69-99.

Champion, C. I., Miller, J. N., Lovett, M. A. \& Blanco, D. R. (1990). Cloning, sequencing, and expression of two class B endoflagellar genes of Treponema pallidum subsp. pallidum encoding

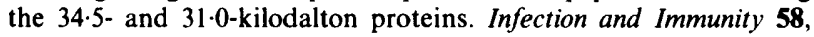
$1697-1704$.

Chatfield, S. N., Fernie, D. S., Penn, C. \& Dougan, G. (1988). Identification of the major antigens of Treponema hyodysenteriae and comparison with those of Treponema innocens. Infection and Immunity 56, 1070-1075.

Cockayne, A. M., Bailey, J. \& Penn, C. W. (1987). Analysis of sheath and core structures of the axial filament of Treponema pallidum. Journal of General Microbiology 113, 1397-1407.

Coleman, J. L. \& BenaCH, J. L. (1989). Identification and characterization of an endoflagellar antigen of Borrelia burgdorferi. Journal of Clinical Investigation 84, 322-330.

Delange, R. J., Chang, J. Y., Shaper, J. H. \& Glazer, A. N. (1976). Amino acid sequence of flagellin of Bacillus subtilis 168. Journal of Biological Chemistry 251, 705-711.

Drake, D. \& Montie, T. C. (1987). Protection against Pseudomonas aeruginosa infection by passive transfer of antiflagellar serum. Canadian Journal of Microbiology 33, 755-763.

GueNTZeL, M. N. \& BERRY, L. J. (1975). Motility as a virulence factor for Vibrio cholerae. Infection and Immunity 11, 890-897.

Harris, D. L., Glock, R. D., Christensen, C. R. \& Kinyon, J. M. (1972). Swine dysentery: inoculation of pigs with Treponema hyodysenteriae (new species) and reproduction of the disease. Veterinary Medicine and Small Animal Clinician 67, 61-64.

Holder, I. A., Wheeler, R. \& Montie, T. C. (1982). Flagellar preparations from Pseudomonas aeruginosa: animal protection studies. Infection and Immunity 35, 276-280.

HoLt, S. C. (1978). Anatomy and chemistry of spirochetes. Microbiological Reviews 42, 114-160.

Hudson, M. J., Alexander, T. J. L. \& Lysons, R. J. (1976). Diagnosis of swine dysentery: spirochaetes which may be confused with Treponema hyodysenteriae. Veterinary Record 99, 495-500.

Isaacs, R. D., Hanke, J. H., Guzman-Verduzco, L.-M., NewPort, G., Agabian, N., Norgard, M. V., Lukehart, S. A. \& Radolf, J. D. (1989). Molecular cloning and DNA sequence analysis of the 37-kilodalton endoflagellar sheath protein gene of Treponema pallidum. Infection and Immunity 57, 3403-3411.

IsAACS, R. D. \& RADOLF, J. D. (1990). Expression in Escherichia coli of the 37-kilodalton endoflagellar sheath protein of Treponema pallidum by use of the polymerase chain reaction and a T7 expression system. Infection and Immunity 58, 2025-2034.

Joseph, R. \& Canale-Parola, E. (1972). Axial fibrils of anaerobic spirochetes: ultrastructure and chemical characteristics. Archiv für Mikrobiologie 81, 146-168

KenNedy, M. J., Rosnick, D. K., UlRich, R. G. \& YanCeY, R. J., JR. (1988). Association of Treponema hyodysenteriae with porcine intestinal mucosa. Journal of General Microbiology 134, 1565-1576.

Kent, K. A., Sellwood, R., Lemcke, R. M., BurRows, M. R. \& LYsONS, R. J. (1989). Analysis of the axial filaments of Treponema hyodysenteriae by SDS-PAGE and immunoblotting. Journal of General Microbiology 135, 1625-1632.

Kuwajima, G., Asaka, J.-I., Fujiwara, T., Node, K. \& Kondo, E. (1986). Nucleotide sequence of the hag gene encoding flagellin of Escherichia coli. Journal of Bacteriology 168, 1479-1483.

LAEMMLI, U. K. (1970). Cleavage of structural proteins during the assembly of the head of bacteriophage T4. Nature, London 227, 680685.

Limberger, R. J. \& Charon, N. W. (1986). Treponema phagedenis has at least two proteins residing together on its periplasmic flagella. Journal of Bacteriology 166, 105-112.

Lukehart, S. A., TAM, R. M., Hom. J., Baker-Zander, S. A., Holmes, K. K. \& Nowinski, R. C. (1985). Characterization of monoclonal antibodies to Treponema pallidum. Journal of Immunology 134, 585 592.

Martin, J. H. \& Savage, D. C. (1988). Cloning, nucleotide sequence, and taxonomic implications of the flagellin gene of Roseburia cecicola. Journal of Bacteriology 170, 2612-2617.

Miller, D. P., Toivio-KinNuCan, M., WU, G. \& Wilt, G. R. (1988). Ultrastructural and electrophoretic analysis of Treponema hyodysenteriae axial filaments. American Journal of Veterinary Research 49, 786-789.

Mrtchison, M., Rood, J. I., Faine, S. \& Adler, B. (1991). Molecular analysis of a Leptospira borgpetersenii gene encoding an endoflagellar subunit protein. Journal of General Microbiology 137, 1529-1536.

MOROOKA, T., UmedA, A. \& AMAKo, K. (1985). Motility as an intestinal colonization factor for Campylobacter jejuni. Journal of General Microbiology 131, 1973-1980.

Norris, S. J., Charon, N. W., CoOK, R. G., Fuentes, M. D. \& LIMBERGER, R. J. (1988). Antigenic relatedness and N-terminal sequence homology define two classes of periplasmic flagellar proteins of Treponema pallidum subsp. pallidum and Treponema phagedenis. Journal of Bacteriology 170, 4072-4082.

Ochi, H., Ohtsuka, H., Yokota, S.-I., Uezumi, I., Terashima, M., IRIE, K. \& NoGUCHI, H. (1991). Inhibitory activity on bacterial motility and in vivo protective activity of human monoclonal antibodies against flagella of Pseudomonas aeruginosa. Infection and Immunity 59, 550-554.

Pallesen, L. \& Hindersson, P. (1989). Cloning and sequencing of a Treponema pallidum gene encoding a 31.3-kilodalton endoflagellar subunit (FlaB2). Infection and Immunity 57, 2166-2172.

Parales, J., JR \& GreenberG, E. P. (1991). N-Terminal amino acid sequences and amino acid compositions of the Spirochaeta aurantia flagellar filament polypeptides. Journal of Bacteriology 173, 13571359.

PaVlovskis, O. R., Rollins, D. M., Haberberger, R. L., JR, Green, A. E., Habash, L., Strocko, S. \& Walker, R. I. (1991). Significance of flagella in colonization resistance of rabbits immunized with Campylobacter spp. Infection and Immunity 59, 2259-2264.

Reviere, G. R., Weisz, K. S., Adams, D. F. \& Thomas, D. D. (1991). Pathogen-related oral spirochetes from dental plaque are invasive. Infection and Immunity 59, 3377-3380.

RichARDSON, K. (1991). Roles of motility and flagellar structure in pathogenicity of Vibrio cholerae: analysis of motility mutants in three animal models. Infection and Immunity 59, 2727-2736.

Šadžlene, A., Thomas, D. D., Bundoc, V. G., Holt, S. C. \& Barbour, A. G. (1991). A flagella-less mutant of Borrelia burgdorferi. Journal of Clinical Investigation 88, 82-92.

Stanton, T. B. (1992). Proposal to change the genus designation Serpula to Serpulina gen. nov. containing the species Serpulina hyodysenteriae comb. nov. and Serpulina innocens comb. nov. International Journal of Systematic Bacteriology 42, 189-190.

TAYLOR, D. J. \& AleXANDeR, T. J. L. (1971). The production of dysentery in swine by feeding cultures containing a spirochete. British Veterinary Journal 127, 58-61.

Towbin, H., Staehelin, T. \& Gordon, J. (1979). Electrophoretic transfer of proteins from polyacrylamide gels to nitrocellulose sheets: procedure and some applications. Proceedings of the National Academy of Sciences of the United States of America 76, 4350-4354.

Wallich, R., Moter, S. E., Simon, M. M., Ebnet, K., Heiberger, A. \& KRAMER. M. D. (1990). The Borrelia burgdorferi flagellum- 
associated 41-kilodalton antigen (flagellin): molecular cloning, expression, and amplification of the gene. Infection and Immunity 58, 1711-1719.

Wassenaar, T. M., Bleumink-Pluym, N. M. C. \& van Der Zeijst, B. A. M. (1991). Inactivation of Campylobacter jejuni flagellin genes by homologous recombination demonstrates that $f l a A$ but not $f a B$ is required for invasion. EMBO Journal 10, 2055-2061.

WEI, L.-N. \& JoYs, T. M. (1985). Covalent structure of three phase-1 flagellar filament proteins of Salmonella. Journal of Molecular Biology 186, 791-803. 